\title{
Role of Serotonin in Development of Varices in Patients with Cirrhosis
}

\author{
Adel Awad Mostafa ${ }^{1}$, Naglaa El-Toukhy Ramadan, \\ Mohamed Hossam El-Din Zaghloul ${ }^{2}$, Mohamed E. Salem Farag \\ ${ }^{1}$ Hepatology, Gastroenterology and Infectious Diseases Department, Faculty of Medicine, \\ Benha University-Benha-Egypt. \\ ${ }^{2}$ Clinical Pathology Department, Faculty of Medicine - Mansoura University-Mansoura -Egypt \\ ${ }^{3}$ Hepatology, Gastroenterology and Infectious Diseases Department, \\ Shebein El-Kom Teaching Hospital-Shebein El-Kom-Egypt
}

\section{Corresponding Author Mohamed E. Salem Farag}

\section{Mobile: 01002699542}

E mail: meltantawy2006@yah oo.com

Key words: Serotonin- Varices in Patients with Cirrhosis- MELD score.
Background and study aim: Serotonin is a one of the monoamine neurotransmitters secreted by serotonergic nerve endings in multiple sites in the brain and gastrointestinal tract wall. The presence of serotonin receptors on hepatic stellate cells can cause contraction of these cells closing the sinusoidal fenestrae and raising the portal vein pressure. The aim of this work is to study the relation between free serotonin level and the presence of varices in patients with cirrhosis.

Patients and Methods: This prospective case control study was carried out on 70 patients with liver cirrhosis attended or admitted to Hepatology Department in Shebein El-Kom Teaching Hospital within the period between May and October 2015. They divided into two groups: Group 1: 40 patients with varices diagnosed by upper GIT endoscopy. Group 2: 30 patients without varices. In addition, 20 healthy persons served as control group (Group 3). All subjects were subjected to full history taking, clinical examination and laboratory investigation including plasma free serotonin by Enzyme Linked Immunosorbant Assay (ELISA).

Results: serum serotonin level in group I was significantly higher than group II and control group. Serum serotonin level was significantly correlated to esophageal varices grade, Child, MELD and updated MELD scores. It was also clear that serotonin level rises significantly with higher grades of esophageal varices.

Conclusion: Free serotonin had a good power of prediction for development of varices and correlated well with severity of liver disease in patients with cirrhosis assessed by Child, MELD and updated MELD scores as well as OV grade.

\section{INTRODUCTION}

Portal hypertension which is considered as one of the most important complications of liver cirrhosis is associated with development of a hyperdynamic circulation and complications such as ascites, hepatic encephalopathy and oesophago-gastric varices. Patients with cirrhosis and gastro-oesophagealvarices have a hepatic venous pressure gradient during hemodynamic catheterization of at least 10-12 $\mathrm{mmHg}$ [1].

Gastroesophageal varices are present in approximately $50 \%$ of patients with liver cirrhosis. Their presence correlates with the severity of liver disease.
Patients without varices develop them at a rate of $8 \%$ per year [2] and the progression from small to large varices occurs in 10 to $20 \%$ of cases yearly. The most important predictor of hemorrhage is the size of varices, with the highest risk of first hemorrhage occurring in patients with large varices, about $15 \%$ per year [3].

Variceal bleeding is associated with a high morbidity and mortality. The mortality associated with each episode of variceal bleeding ranges from $17 \%$ to $57 \%$ [4].

The incidence of bleeding can be reduced with nonselective betablockers [5]. 
It is also suggested that prophylactic endoscopic variceal band ligation can decrease the incidence of variceal bleeding and mortality in patients with liver cirrhosis who have large varices [6].

The prevalence of oesophageal varices among cirrhotic patients is variable, ranging from $24 \%$ to $80 \%$. Therefore, endoscopic screening of all patients with liver cirrhosis would result in a large number of unnecessary additional burdens to endoscopic units [7].

Therefore, the identification of non endoscopic, non invasive methods that can accurately predict esophageal varices, particularly large esophageal varices in cirrhotic patients and help to identify patients at greatest risk and thereby reduce the necessity of endoscopic screening [8].

Several studies have examined how to identify patients with varices using non-invasive or minimally invasive methods to avoid endoscopy in patients with a low risk of varices. These studies include biochemical, clinical and ultrasound parameters, transient elastography, CT scanning and video capsule endoscopy [9].

Serotonin is released from platelets at the site of injury in the liver to regulate the process of hepatic regeneration and fibrosis [10]. In the pathogensis of cirrhosis the hepatic stellate cells (HSC) are transformed into myofibroblasts under the influence of the inflammatory mediators secreted by the damaged liver cells [11]. There's also increased number of 5HT receptors on the HSC cell membrane enhancing the cell response to serotonin. This can cause contraction of these cells closing the sinusoidal fenestrae and raising the portal vein pressure [12].

Rudic, et al. [13] found that mean plasma free serotonin was higher in patients with varices than in patients without varices $(\mathrm{P}<0.05)$. Also, they found that the correlation of plasma serotonin concentration and fundal varices was highly significant $(\mathrm{P}<0.01)$, and they proved that the mean plasma free serotonin level was much higher in patients who had esophageal and gastric fundal varices than in patients who had only esophageal varices $(\mathrm{P}<0.01)$.

Also, Abdelkader, et al. [14] concluded that plasma free serotonin level could possibly be used as a noninvasive predictive method for the presence of gastroesophageal varices.

The aim of this work was to study the association between free serotonin concentration in plasma and the development of varices in patients with cirrhosis.

\section{PATIENTS AND METHODS}

\section{I- Patients:}

This prospective case control study was carried out on 70 patients with liver cirrhosis attended or admitted to Hepatology Department in Shebein El-Kom Teaching Hospital within the period between May and October 2015.

\section{They divided into two groups:}

Group 1: 40 patients with varices diagnosed by upper GIT endoscopy. Group 2: 30 patients without varices. In addition, 20 healthy persons served as control group (Group 3).

The study protocol was approved by the scientific committee of Benha faculty of medicine.

\section{Selection of patients \\ Inclusion criteria:}

Patients with cirrhosis with or without varices, Cirrhosis was diagnosed by clinical manifestations, laboratory investigations and ultrasonography [15]. Varices were diagnosed by upper GIT endoscopy.

\section{Exclusion Criteria :}

Patients with primary and secondary liver tumors, patients with history of depression and patients receiving selective serotonin reuptake inhibitors (SSRIs) and other antipsychotics were excluded from the study.

\section{II- Methods :}

All patients were submitted to the following:

1- Full history taking and thorough clinical examination paying specific attention to the manifestations of liver cirrhosis e.g. palmer erythema, jaundice, ascites, lower limb edema, encephalopathy and splenomegaly.

2- Laboratory investigations including: Complete blood count (CBC)-ALT (Alanine aminotransferase)-AST (aspartate amino-transferase)Serum bilirubin (total, direct) - Serum albumin - P.T. (Prothrombin time) - INR (international normalized ratio)- Serum creatinine-HCV-Ab (Hepatites $\mathrm{C}$ virus antibody) and $\mathrm{HBs} \mathrm{Ag}$ (Hepatites B virus surface antigen).

3-Assessment of liver cirrhosis by:

- Child Turcotte Pugh (CTP) classification [16].

- MELD score (Model for End Stage Liver Disease) [17]. 
- Updated MELD score (uMELD) [18].

4- Abdominal ultrasonography for evaluation of: To confirm presence of cirrhosis exclude focal lesions to rule out patients with primary and secondary liver tumors from the study, determine spleen size and to detect portal vein diameter and ascites.

5- Upper gastrointestinal endoscopy and grading of esophageal varices: According to Dancygier and Ragon [19].

6- Specific investigations: Measurement of plasma free serotonin by ELISA.

\section{Statistical analysis:}

The data were coded, entered and processed on computer using SPSS (version 18).The results were represented in tabular and diagrammatic forms then interpreted. Mean, standard deviation, range, frequency, and percentage were use as descriptive statistics.

The following test was done: Chi-Square test $X^{2}$ was used to test the association variables for categorical data. Student's t-test was used to assess the statistical significance of the difference between two population means in a study involving independent samples. ANOVA (F test) for normally quantitative variables, to compare between more than two groups, and Post Hoc test (LSD) for pairwise comparisons

$P$ value was considered significant as the following: $* \mathrm{P}>0.05$ : Non significant. $* \mathrm{P} \leq 0.05$ : Significant

\section{RESULTS}

The demographic features and characteristic of patients were summarized in table 1 and 2 .

The study was carried out on 70 patients with liver cirrhosis attended or admitted to Hepatology Department in Shebein El-Kom Teaching Hospital divided into 2 groups according to presence of varices within the period between May and
October 2015. In addition, 20 healthy persons served as control group. There was no statistically significant difference between groups as regards the age and gender; however varices tend to be more common in males than females. Varices were found in $(57.14 \%)$ of patients with cirrhosis.

There was no statistically significant difference between the groups as regard to the residence and occupation, however patients with varices tend to be from rural areas and work as farmers.

Cases of varices have higher child score, when compared with cases without varices with statistical significance.

MELD and updated MELD scores were significantly higher in group I, when compared to group II with statistical significance.

Group I has higher serotonin level than group II and control group with statistical significance (Table 3 and Figure 1),

Patients with gastric fundal and esophageal varices have higher serotonin level than patients with esophageal varices only (Table 4).

Patients with higher grades of varices have higher serotonin level (Table 5 and Figure 2).

ROC curve analysis of serum free serotonin level revealed that, at a cut off value of $202 \mathrm{nmol} / \mathrm{L}$; the sensitivity for detection of varices was $96.7 \%$, specificity $80.0 \%$, positive predictive value (PPV) was $78.37 \%$, negative predictive value (NPV) was $80.0 \%$; area under the curve was 92 denoting good predictive value of serotonin in prediction of varices (Table 6 and Figure 3).

There is significant correlation between serotonin level and serum albumin, total billirubin, INR, platelets count, MELD, updated MELD and Child classification indicating that the serum serotonin level is correlated to the severity of liver function decompensation in patients with cirrhosis (Table 7 and Figures 4,5,6,7). 
Table (1) : Demographic features and characteristic of patients

\begin{tabular}{|c|c|c|c|}
\hline Characteristic & $\begin{array}{c}\text { Group I (patients with } \\
\text { varices) } \\
\mathbf{N}=\mathbf{4 0}(\mathbf{5 7 . 1 4 \% )}\end{array}$ & $\begin{array}{c}\text { Group II (Patients without } \\
\text { varices) } \\
\mathrm{N}=\mathbf{3 0}(\mathbf{4 2 . 8 6 \% )}\end{array}$ & P-value \\
\hline $\begin{array}{l}\text { Age(years) } \\
\text { Range } \\
\text { Mean } \pm \text { SD }\end{array}$ & $\begin{array}{c}25-61 \\
44.65 \pm 9.55\end{array}$ & $\begin{array}{c}25-61 \\
43 \pm 9.42\end{array}$ & 0.474 \\
\hline $\begin{array}{l}\text { Gender } \\
\text { Male } \\
\text { Female }\end{array}$ & $\begin{array}{l}25(62.5 \%) \\
15(37.5 \%)\end{array}$ & $\begin{array}{l}20(66.7 \%) \\
10(33.3 \%)\end{array}$ & 0.714 \\
\hline $\begin{array}{c}\text { Residence } \\
\text { Urban } \\
\text { Rural }\end{array}$ & $\begin{array}{l}14(35 \%) \\
26(65 \%)\end{array}$ & $\begin{array}{c}9(30 \%) \\
21(70 \%)\end{array}$ & 0.654 \\
\hline $\begin{array}{l}\text { Occupation } \\
\quad \text { Farmer } \\
\text { Non-farmer }\end{array}$ & $\begin{array}{l}26(65 \%) \\
14(35 \%)\end{array}$ & $\begin{array}{c}22(73.3 \%) \\
8(26.7 \%)\end{array}$ & 0.457 \\
\hline Smoking & $14(35 \%)$ & $16(53.3 \%)$ & 0.125 \\
\hline
\end{tabular}

*= significant

Table (2) : Clinical characters of the studied patients

\begin{tabular}{|c|c|c|c|}
\hline HCV & $32(80 \%)$ & $25(83.3 \%)$ & 0.723 \\
\hline HBV & $8(20 \%)$ & $5(16.7 \%)$ & 0.737 \\
\hline \multicolumn{4}{|c|}{ Severity of liver disease } \\
\hline $\begin{array}{l}\text { Child A } \\
\text { Child B } \\
\text { Child C }\end{array}$ & $\begin{array}{c}7(17.5 \%) \\
18(45 \%) \\
15(37.5 \%)\end{array}$ & $\begin{array}{l}18(60 \%) \\
9(30 \%) \\
3(10 \%)\end{array}$ & $0.001^{*}$ \\
\hline $\begin{array}{l}\text { MELD score } \\
\text { Mean } \pm \text { SD }\end{array}$ & $20.07 \pm 6.73$ & $11.56 \pm 6.53$ & $0.000 *$ \\
\hline $\begin{array}{l}\text { uMELD score } \\
\text { Mean } \pm \text { SD }\end{array}$ & $4.13 \pm .88$ & $3.16 \pm .80$ & $0.000 *$ \\
\hline
\end{tabular}

Table (3): Serotonin levels in the studied groups

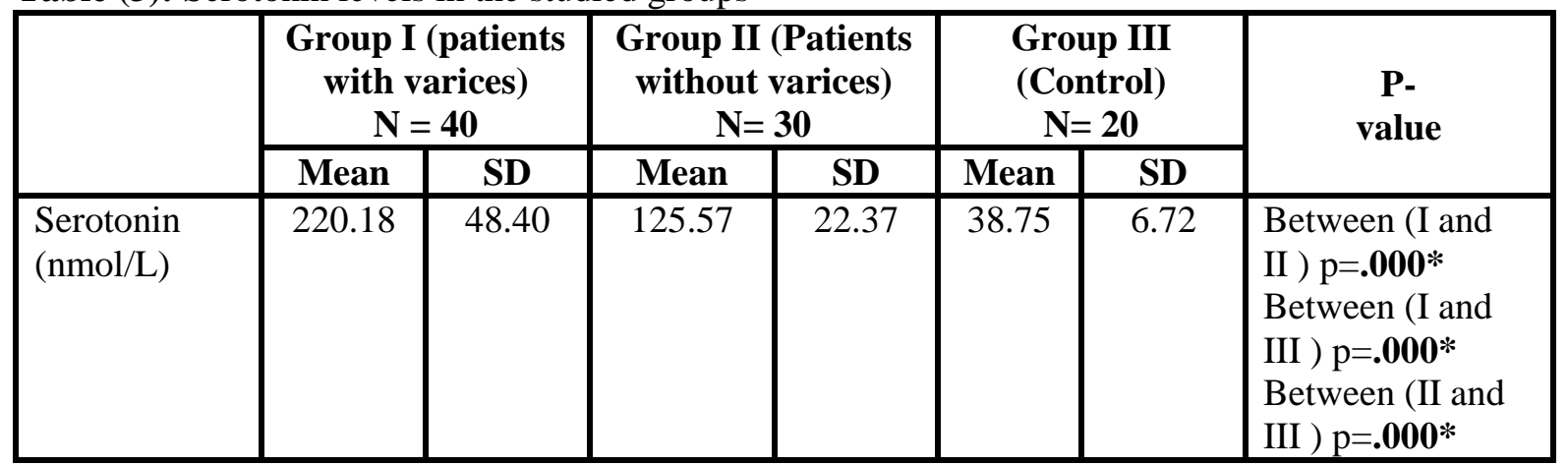

$*$ = significant 


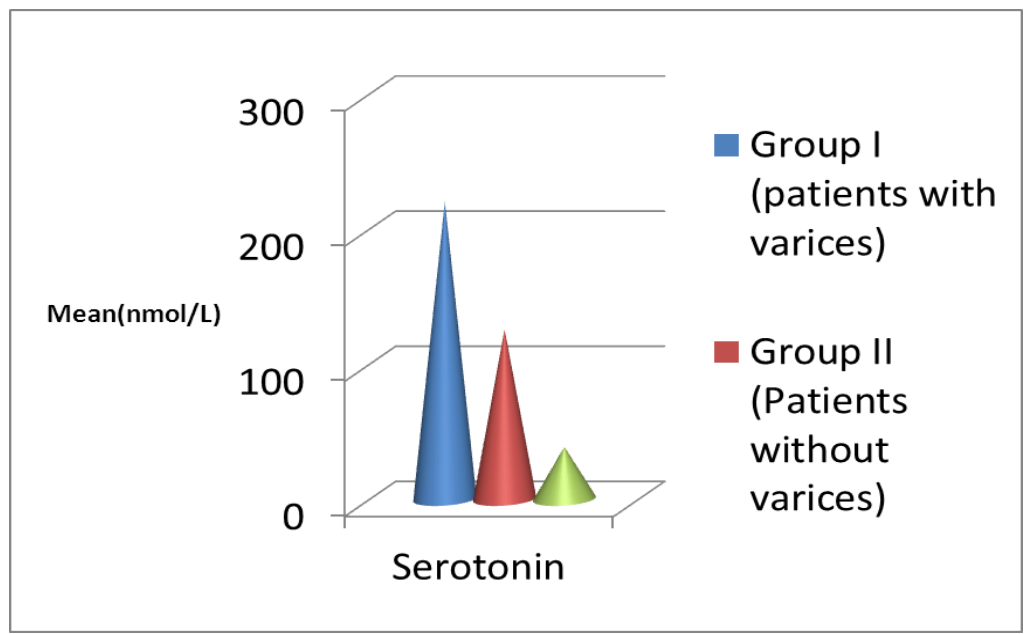

Figure (1): Serotonin levels in the studied groups

Table (4) : Comparison between patients with gastric fundal and esophageal varices and patients with only esophageal varices according to serum level of serotonin

\begin{tabular}{|l|c|c|c|c|c|}
\hline & \multicolumn{2}{|c|}{$\begin{array}{c}\text { Esophageal varices with no gastric } \\
\text { fundal varices } \\
\mathbf{N = 3 3}\end{array}$} & \multicolumn{2}{c|}{$\begin{array}{c}\text { Gastric fundal varices } \\
\mathbf{N = 7}\end{array}$} & \multirow{2}{*}{$\begin{array}{c}\text { P- } \\
\text { value }\end{array}$} \\
\cline { 2 - 5 } & Mean & SD & Mean & SD & \\
\hline $\begin{array}{l}\text { Serotonin } \\
\text { (nmol/L) }\end{array}$ & 206.51 & 39.36 & 284.5714 & 33.21073 & \multirow{0}{*000*}{} \\
\hline
\end{tabular}

* = significant

Table (5) : Association between serotonin and grades of varices

\begin{tabular}{|l|l|c|c|c|c|c|c|c|c|}
\hline & \multicolumn{2}{|c|}{$\begin{array}{c}\text { Grade I } \\
\text { varices } \\
\text { N= 10 }\end{array}$} & \multicolumn{2}{c|}{$\begin{array}{c}\text { Grade II } \\
\text { varices } \\
\text { N= 10 }\end{array}$} & \multicolumn{2}{c|}{$\begin{array}{c}\text { Grade III } \\
\text { varices } \\
\text { N= 10 }\end{array}$} & \multicolumn{2}{c|}{$\begin{array}{c}\text { Grade IV } \\
\text { varices } \\
\text { N= 10 }\end{array}$} & \multirow{2}{*}{$\begin{array}{c}\text { P- } \\
\text { value }\end{array}$} \\
\cline { 2 - 9 } & Mean & SD & Mean & SD & Mean & SD & Mean & SD & \\
\hline $\begin{array}{l}\text { Serotonin } \\
(\mathrm{nmol} / \mathrm{L})\end{array}$ & 197.4 & 22.95 & 210.4 & 38.99 & 231.5 & 51.7 & 241.4 & 64.08 & $\mathbf{. 0 0 0}^{*}$ \\
\hline
\end{tabular}

$*$ = significant

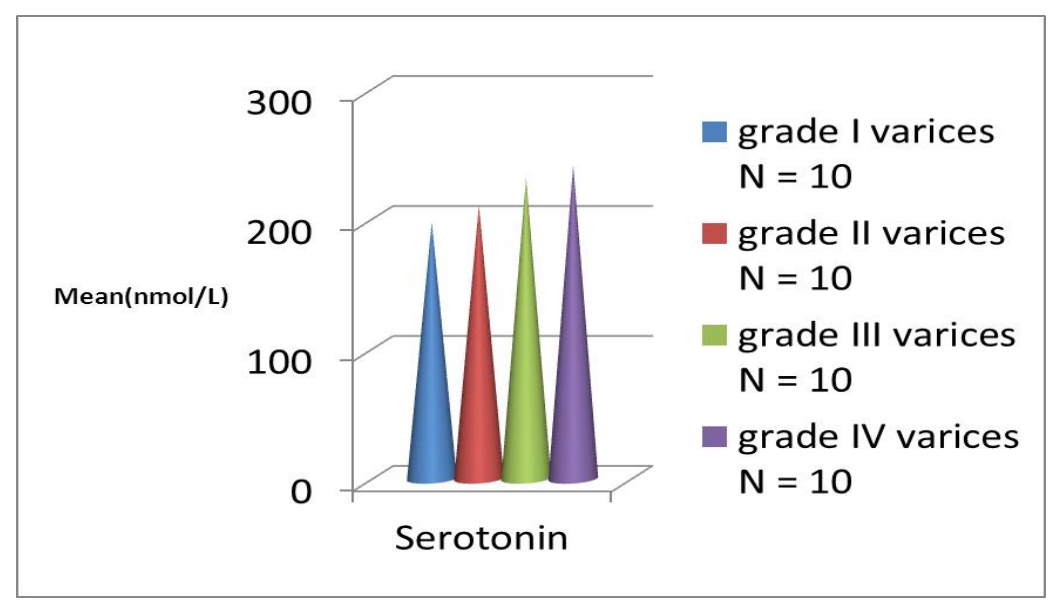

Figure (2): Association between serotonin and grades of varices 
Table (6) : Serotonin as a marker for Oesophageal varices

\begin{tabular}{|c|c|c|c|c|c|c|c|}
\hline Test & Cutoff & Sensitivity \% & Specificity \% & PPV\% & NPV\% & AUC & $\begin{array}{c}\text { P } \\
\text { value }\end{array}$ \\
\hline $\begin{array}{l}\text { Serotonin } \\
\text { (nmol/L) }\end{array}$ & 202 & 96.7 & 80 & 78.37 & 80 & .92 & $\mathbf{0 . 0 0 2} *$ \\
\hline
\end{tabular}

* = significant

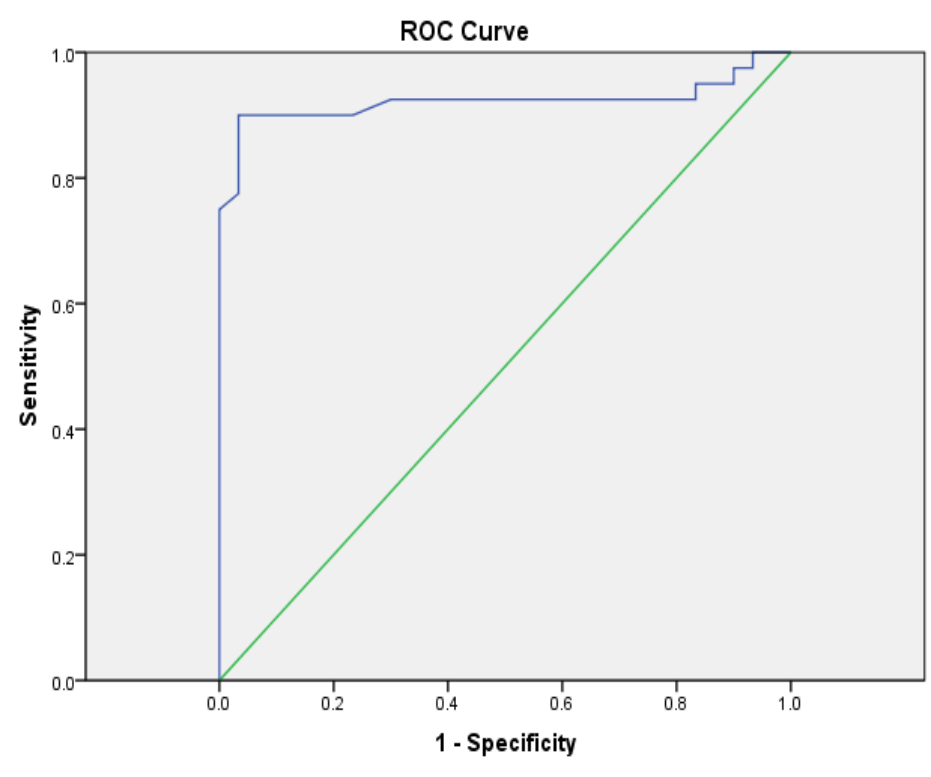

Diagonal segments are produced by ties.

Figure (3): Receiver operative curve analysis of serotonin

Table (7) : Correlation between serotonin and other variables in studied patients

\begin{tabular}{|l|l|l|}
\hline Variables & \multicolumn{1}{c|}{ Serotonin } & \multicolumn{1}{c|}{ Pearson correlation } \\
r & \multicolumn{1}{c|}{ P value } \\
\hline Child score & .300 & $\mathbf{0 . 0 1 2}$ \\
\hline Creatinin & .171 & 0.158 \\
\hline Albumin & -.558 & $\mathbf{0 . 0 0 0}$ \\
\hline Platelets & -.739 & $\mathbf{0 . 0 0 0}$ \\
\hline Bilirubin & .412 & $\mathbf{0 . 0 0 0}$ \\
\hline INR & .630 & $\mathbf{0 . 0 0 0}^{*}$ \\
\hline MELD & .345 & $\mathbf{0 . 0 0 3}^{*}$ \\
\hline Updated MELD & .273 & $\mathbf{0 . 0 2 2}$ \\
\hline Esophageal varices grades & .358 & $\mathbf{0 . 0 2 3}^{*}$ \\
\hline
\end{tabular}

$*$ = significant 


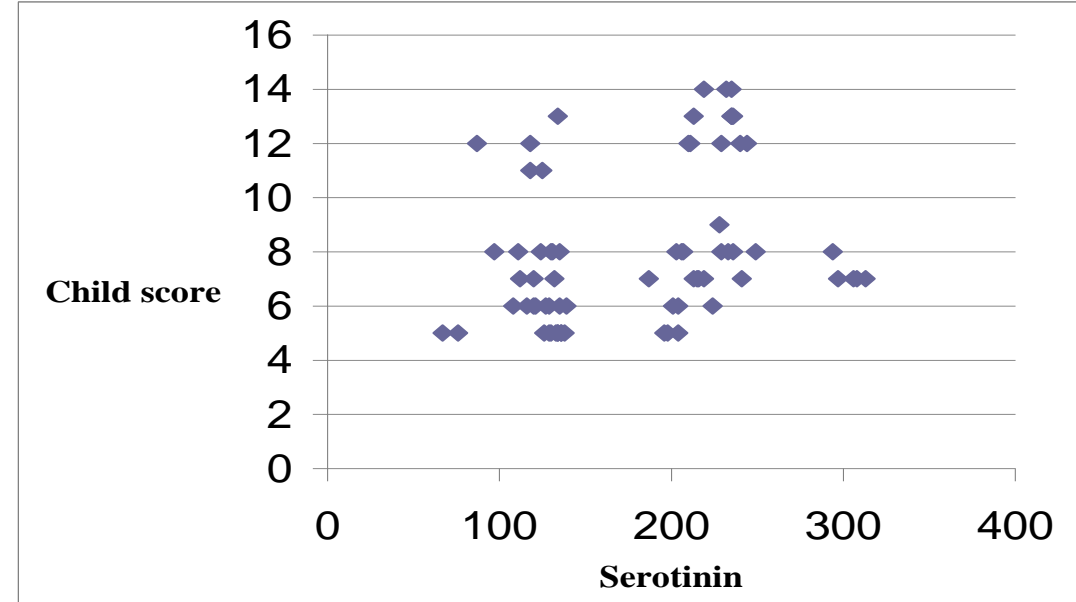

Figure (4): Correlation between serotonin and child score

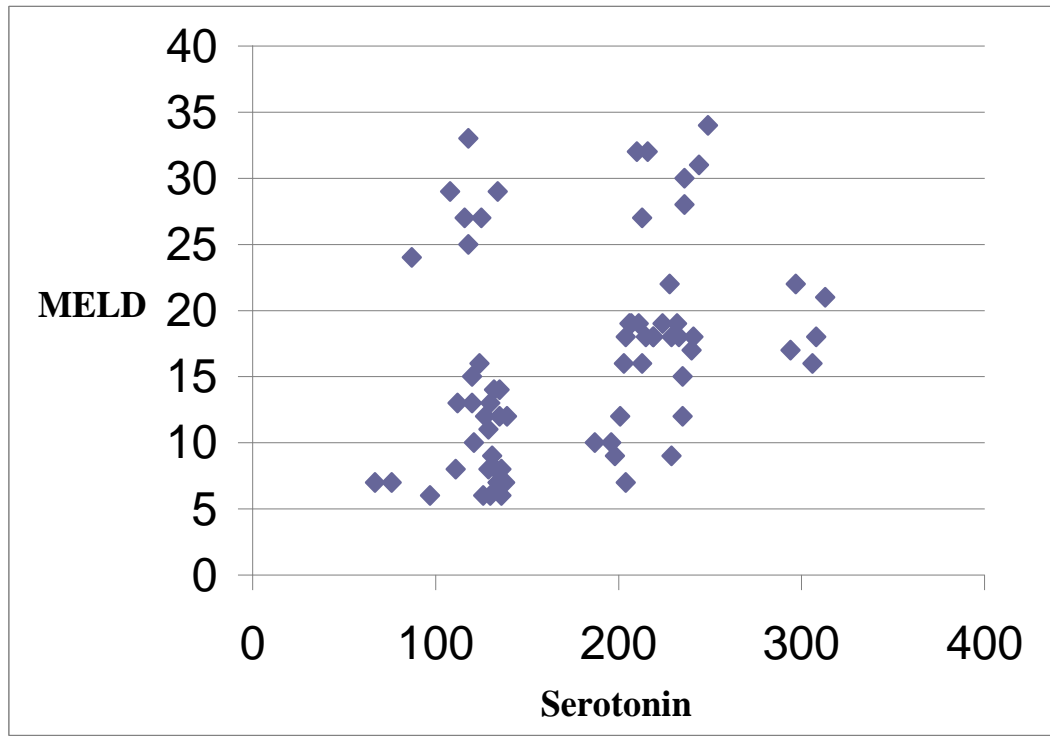

Figure (5): Correlation between serotonin and MELD

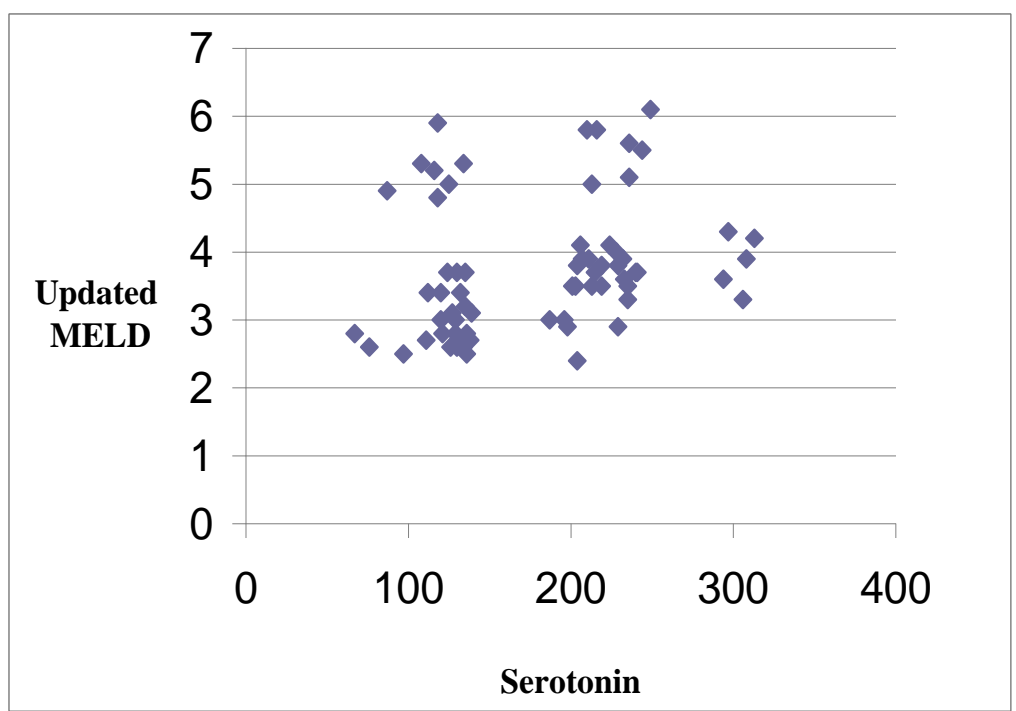

Figure (6): Correlation between serotonin and updated MELD

Mostafa et al., Afro-Egypt J Infect Endem Dis 2017; 7(4): 177-185 http://mis.zu.edu.eg/ajied/home.aspx 


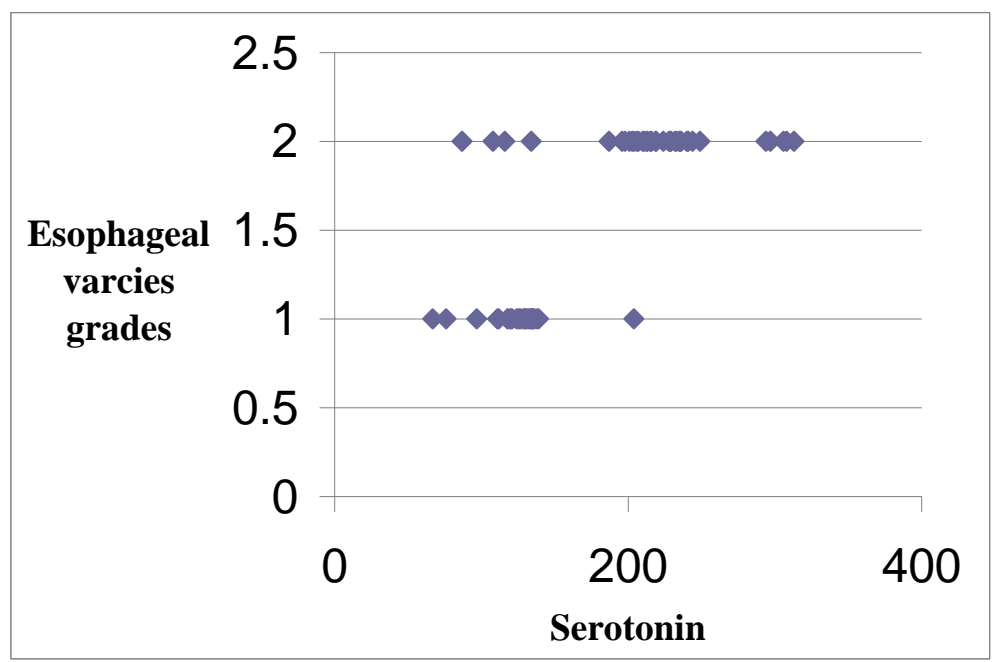

Figure (7): Correlation between serotonin and Esophageal varices grades

\section{DISCUSSION}

Portal hypertension is a serious condition with various severe life threatening consequences most important of which is varices development and bleeding. This study aims at expolring the correlation between serum serotonin level as a vasoactive amine and presence of varices.

Results of the present study revealed that, free serotonin level was significantly higher in patients with varices $($ mean $=220.18 \pm 48.40 \mathrm{nmol} / \mathrm{L})$ than patients without varices $($ mean $=125.57 \pm 22.37$ $\mathrm{nmol} / \mathrm{L}$ ) and control group (mean $=38.75 \pm 6.72$ $\mathrm{nmol} / \mathrm{L})$ (P value $=0.000)$. Also, Patients with gastric fundal and esophageal varices have higher serotonin level than patients with esophageal varices only (Table 4). This results agreed with the results of the study done by Rudic et al. [13] in which free serotonin level was investigated and they found that mean plasma free serotonin was higher in patients with esophageal varices than in patients without varices $(\mathrm{P}<0.05)$. Also, they found that the correlation of plasma serotonin concentration and fundal varices was highly significant $(\mathrm{P}<0.01)$, and they proved that the mean plasma free serotonin level was much higher in patients who had esophageal and gastric fundal varices than in patients who had only esophageal varices $(\mathrm{P}<0.01)$. Also, this result agreed with the results of the study done by Abdelkader et al. [14] in which they concluded that plasma free serotonin level could possibly be used as a noninvasive predictive method for the presence of gastroesophageal varices.

In the present study patients with higher grades of varices have higher serotonin level (Table 5 and Figure 2). This results agreed with the results of the study done by Abdelkader, et al. [14] in which they found that a highly significant stepwise progressive increase in the free serotonin level was recorded through grades of esophageal varices. This results agreed also with the results of the study done by Hammam et al. [20] in which they concluded that serum serotonin level is significantly correlated to the grade of esophageal varices in patients with viral hepatitis related cirrhosis. This result disagreed with the result of Rudic et al. [13] who found that no significant difference between the serotonin concentration and the size of esophageal varices, this difference may be due to small number of the studied patients (33) in their study.

ROC curve analysis of serum free serotonin level revealed that, at a cut off value of $202 \mathrm{nmol} / \mathrm{L}$; the sensitivity for detection of varices was $96.7 \%$, specificity $80.0 \%$, positive predictive value (PPV) was $78.37 \%$, negative predictive value (NPV) was $80.0 \%$; area under the curve was 92 denoting good predictive value of serotonin in prediction of varices. These results are comparable to those reported by Abdelkader et al. [14] who concluded that plasma free serotonin level could possibly be used as a noninvasive predictive method for the presence of gastroesophageal varices (Table 6 and Figure 3).

In the present study, there is significant correlation between serotonin level and serum albumin, total billirubin, INR, platelets count, MELD, updated MELD and Child classification indicating that the serum serotonin level is correlated to the severity of liver function decompensation in patients with cirrhosis (Table 7). 


\section{CONCLUSION}

This study concluded that Varices were found in $57.14 \%$ of cirrhotic patients. MELD and updated MELD scores were significantly higher in patients with varices. Free serotonin may have a role in the development of gastric fundal varices, indicating the clinical value of serotonergic receptor blockers in these patients. Free serotonin is significantly increased in cirrhotic patients with varices; it had a good power of prediction for development of varices. And correlated well with severity of liver disease in patients with cirrhosis assessed by Child, MELD and updated MELD scores as well as OV grade.

Funding: None.

Conflicts of interest: None.

Ethical approval:Approved .

\section{REFERENCES}

1- Garcia-Tsao G, Sanyal AJ , Grace N. Prevention and management of esophageal varices and variceal bleeding in cirrhosis. Hepatology 2007; 46(3): 922-38.

2- Merli M, Nicolini G, Angeloni S, Rinaldi V, De Santis A, Merkel C. Incidence and natural history of small esophageal varices in cirrhotic patients. J. Hepatol 2003; 38:266-72.

3- Augustin S, Millan L, Gonzalez A, Martell M, Gelabert A, Segarra A. Detection of early portal hypertension with routine data and liver stiffness with asymptomatic liver disease. A prospective study. J. Hepatol 2013.22:25060.

4- Garcia-Tsao G, Bosch J , Groszmann R. Portal hypertension and variceal bleeding unresolved issues. Summary of an American association for the study of liver diseases and European association for the study of the liver. Single-topic conference. Hepatology 2008; 47: 1764-72.

5- Tripathi D , Hayes PC. Review article: a drug therapy for the prevention of variceal haemorrhage. Aliment Pharmacol Ther 2001; 15: 291-310.

6- Khuroo MS, Farahat KL, Sofi AA. Meta-analysis: endoscopic variceal ligation for primary prophylaxis of oesophageal variceal bleeding. Aliment Pharmacol Ther 2005; 21: 347-361.

7- de Franchis R. Noninvasive diagnosis of esophageal varices: is it feasible? Am. J. Gastroenterol 2006; 101(11):2520-2

8- Berzigotti A, Gilabert R, Abraldes JG, Nicolau C, Bru C, Bosch J. Non invasive prediction of clinically significant portal hypertension and oesophageal varices in patients with compensated liver cirrhosis. Am.J. Gastroenterol 2008. 103(5), 1159-67.

9- de Franchis R. Non-invasive (and minimally invasive) diagnosis of oesophageal varices. $J$. Hepatol 2008; 49:520-7.

10- Ruddell RG, Mann DA, Ramm GA. The function of serotonin within the liver. J Hepatol 2008; 48: 666-675.

11- Bataller R, Brenner DA. Liver fibrosis. J. Clin. Invest 2005. 115, $209-218$.

12- Ruddell RG, Oakley F, Hussain Z, Yeung I., Bryan-Liuka, LJ, Ramm GA. A role for serotonin (5-HT) in hepatic stellate cell function and liver fibrosis. Am J Pathol 2006; 169:861876.

13- Rudic JS, Culafic DM, Mirkovic DS, Jesic RD, Krstic MN. Role of serotonin in development of esophageal and gastric fundal varices. World $J$. Gastroenterol. 2010; 16(48): 6135-6138.

14- Abdelkader NA, Abdel Moez AT, Hossam El Deen,M.S , Elsayed Saad W. Free serotonin (5HT) levels in Egyptian patients with esophageal and fundal varices. Egyptian Liver Journal: January 2015 - Volume 5 - Issue 1 - p 15-19.

15- Mura VL, Reverter JC, Flores-Arroyo A, Raffa S, Reverter E, Seijo S. von Willebrand factor levels predict clinical outcome in patients with cirrhosis and portal hypertension. Gut 2011; 60: 1133-8.

16-Pugh RN, Murray-Lyon I.M, Dawson JL, Pietroni MC, Williams R. Transection of the oesophagus for bleeding oesophageal varices. $\mathrm{Br}$. $\mathrm{J}$. Surg. 1973; 60: 646-649.

17- Kamath PS, Wiesner RH, Malinchoc M, Kremers W, Therneau TM, Kosberg CL et al. A model to predict survival in patients with end-stage liver disease. Hepatol 2001; 33: 464-70.

18- Sharma P, Shaubel DE, Sima CS, Merion RM , Lok SF . Re-weighting the model for end-stage liver disease score components. Gastroenterology 2008; 135: 1575-1581.

19- Dancygier H, Ragon NJ. Approach to the patient with Portal Hypertension. In: Clinical Hepatology (v1) 2010. ch.53:p593-602.

20- Hammam AA, Sallam MM, Jouda AA, Metwally A , Ahmed AM. The Relation between Serum Serotonin and Esophageal Varices in Egyptian Patients with Viral Hepatitis Related Cirrhosis: A Case-Control Study. Journal of GHR 2016 August 21; 5(4): 2136-2139. 